\title{
Serial measurements of peak expiratory flow and responsiveness to methacholine in the diagnosis of aluminium potroom asthma
}

\author{
Johny Kongerud, Vidar Søyseth, Sherwood Burge
}

\begin{abstract}
Background Obstructive airways disease in aluminium potroom workers has been recognised for over 50 years. There is still controversy about whether this is true occupational asthma.

Methods A cross sectional survey of 379 potroom workers identified 26 subjects with symptoms suggestive of occupational asthma. Of these 26,14 were considered by the plant physician to have occupational asthma and had a measurable $\mathbf{P C}_{20}$ methacholine (provocative concentration causing a $20 \%$ fall in $\mathrm{FEV}_{1}$ ). These 14 were further investigated by serial measurements of peak flow at home and work, symptom diaries, and measurements of methacholine reactivity before and after a three week holiday.
\end{abstract}

Results There was a good correlation between daily symptom scores and minimum peak flow measurements; these showed changes characteristic of occupational asthma in 10 workers, with increased diurnal variation in peak flow and consistent deterioration in relation to work exposure. One further record showed probable occupational asthma and two showed consistent small changes in peak flow related to work exposure more in keeping with an irritant effect. Only one record was inadequate. Methacholine reactivity on a work day was within the normal range in nine of 13 subjects. A doubling of $\mathbf{P C}_{20}$ methacholine occurred in five of nine subjects with occupational asthma in whom repeated estimations were possible.

Conclusions This study confirms the existence of aluminium potroom asthma. The lack of correlation with measurements of non-specific responsiveness suggests that the primary mechanism is one of hypersensitivity, perhaps enhanced by the bronchial irritants also present in the potroom.

Aluminium is produced by electrolytic reduction of alumina (aluminium oxide). The electrolytic cells (pots) are of two types, Søderberg and prebake. In Søderberg pots the anode is baked on the site and carbon has to be added to the top of the pot. The anodes in prebake pots are produced outside the potroom in the carbon plant. Both technologies use an insulated steel cradle with a carbon bottom which acts as a cathode and is connected to the negative terminal of the power source. The prebake technology allows for a more automated process with hoods covering the pot. Although the hoods are closed and the efficiency of the hoods in collecting fumes is better than that seen in Søderberg pots, the hoods have to be removed occasionally when the aluminium is being tapped or when the anode has to be changed. Large amounts of gases (hydrogen fluoride, sulphur dioxide, carbon monoxide, carbon dioxide) and dust containing various fluorides and small amounts of trace metals (vanadium, chromium, and nickel) are emitted at that time. In Søderberg cells essentially the same pollutants are emitted during tapping and addition of extra alumina and aluminium fluoride.

Respiratory disease in potroom workers is well recognised. Fifty years ago Frostad reported respiratory irritation in Norwegian aluminium plant workers with fluorosis. ${ }^{1}$ However, there is still controversy about whether this is true asthma and if so whether it relates to sensitisation or to an irritant effect. ${ }^{2}$

Frequent records of peak expiratory flow (PEF) at home and at work have proved helpful in diagnosing occupational asthma in other situations ${ }^{34}$ and have helped to determine the type of reaction. Tests of bronchial responsiveness carried out in conjunction with measurements of PEF have provided additional support for the diagnosis of occupational asthma. ${ }^{5}$ We have used serial measurements of peak flow and bronchial responsiveness to validate the potroom workers' histories and to characterise their airways disease.

\section{Methods}

The study took place in a small town of 6000 inhabitants in western Norway. The smelter employed $50 \%$ of the local workforce. Medical examinations before employment excluded those who had had asthma since adolescence and those with an $\mathrm{FEV}_{1}$ below $80 \%$ predicted. The smelter had three potroom departments with separate workers. There was one Søderberg pot, one prebake pot with automatic alumina delivery (without the need to lift the pot covers) and one prebake pot with alumina delivery from a circulating vehicle. Table 1 shows the mean levels of exposure and the jobs of the study population. 
Table 1 Levels of exposure estimated from personal samplers worn during the whole workshift by subjects representative of the potroom workers studied $\left(\mathrm{mg} / \mathrm{m}^{3}\right)$

\begin{tabular}{|c|c|c|c|c|c|}
\hline \multirow[b]{2}{*}{$\begin{array}{l}\text { Subject } \\
\text { No }\end{array}$} & \multirow[b]{2}{*}{ Job $(\text { department })^{\star}$} & \multicolumn{2}{|c|}{ Exposure to dust $\dagger$} & \multicolumn{2}{|c|}{ Exposure to fluorides $\ddagger$} \\
\hline & & $\begin{array}{l}\text { Geometric } \\
\text { mean }\end{array}$ & Range & $\begin{array}{l}\text { Geometric } \\
\text { mean }\end{array}$ & Range \\
\hline 1 & Foreman (2) & 1.08 & $0.67-1.83$ & $0 \cdot 25$ & $0.14-0.37$ \\
\hline 2 & Pot operator (3) & $2 \cdot 75$ & $0.60-50 \cdot 0$ & 0.41 & $0 \cdot 22-0 \cdot 88$ \\
\hline 3 & Pot service (3) & $1 \cdot 79$ & $0.07-50 \cdot 0$ & 0.29 & $0 \cdot 12-0.89$ \\
\hline 4 & Studpuller (1) & $5 \cdot 51$ & $3 \cdot 13-20 \cdot 1$ & 1.04 & $0.60-1.99$ \\
\hline 5 & Pot operator (1) & $3 \cdot 83$ & $1 \cdot 66-7 \cdot 14$ & $1 \cdot 09$ & $0 \cdot 78-2 \cdot 06$ \\
\hline 6 & Pot operator (1) & 3.83 & $1 \cdot 66-7 \cdot 14$ & $1 \cdot 09$ & $0 \cdot 78-2 \cdot 06$ \\
\hline 7 & Foreman (1) & 0.54 & & $0 \cdot 20$ & \\
\hline 8 & Pot operator (1) & 3.97 & $1 \cdot 09-15 \cdot 8$ & 0.74 & $0.48-1.54$ \\
\hline 9 & Pot operator (3) & 4.94 & $2 \cdot 83-9 \cdot 88$ & 0.45 & $0 \cdot 25-0 \cdot 80$ \\
\hline 10 & Foreman (2) & $0 \cdot 17$ & $0.12-0.24$ & $0 \cdot 18$ & $0 \cdot 13-0.25$ \\
\hline 11 & Pot operator (1) & $3 \cdot 83$ & $1 \cdot 66-7 \cdot 14$ & 1.09 & $0 \cdot 78-2 \cdot 06$ \\
\hline 12 & Crane operator (3) & $1 \cdot 29$ & $0.36-2.58$ & $0 \cdot 15$ & $0 \cdot 12-0 \cdot 19$ \\
\hline 13 & Pot relining (2) & 1.56 & $0 \cdot 44-15 \cdot 3$ & 0.36 & $0.15-0.64$ \\
\hline 14 & Pot operator (3) & $2 \cdot 75$ & $1 \cdot 60-50 \cdot 0$ & 0.41 & $0.22-0.88$ \\
\hline
\end{tabular}

^Departments 1 and 2 are separate prebake departments. Department 3 is a Søderberg potroom. Pot operator is the most common job in the potrooms and entails working most of the time close to the pots. Pot service workers maintain the pots and the studpuller in the prebake potroom is mainly engaged in anode changing. The crane operator works in a ventilated cabin, and the pot relining operator builds new cathodes.

†The Norwegian hygiene standard is $5.0 \mathrm{mg} / \mathrm{m}^{3}$.

† The Norwegian hygiene standard is $1.0 \mathrm{mg} / \mathrm{m}^{3}$.

SUBJECTS

A cross sectional survey of the potroom workers using the prebake or Søderberg processes in different areas included $96 \%$ ( 379 subjects) of the total workforce; those contacted completed a respiratory questionnaire and had their lung function measured. Workers with wheeze and breathlessness that improved when away from work and who were thought to have asthma after a standardised interview were asked to participate in a longitudinal study of methacholine reactivity provided that their $\mathrm{FEV}_{1}$ exceeded $80 \%$ predicted. Twenty six workers fulfilled these criteria, of whom 21 had at least one $\mathrm{PC}_{20}$ (provocative concentration of methacholine causing a $20 \%$ fall in $\mathrm{FEV}_{1}$ ) at or below $32 \mathrm{~g} / 1$. These workers were then interviewed by the plant physician. The 14 workers who had a history suggestive of occupational asthma form the subjects for this study. Table 2 shows the characteristics of these 14 subjects.

PEF MEASUREMENTS

All subjects were asked to measure peak expiratory flow at least three times daily using a Vitalograph peak expiratory flow meter. Three readings were taken on each occasion and the difference between the best two had to be less than $20 \mathrm{l} /$ minute. If the difference was greater than $20 \mathrm{l} / \mathrm{min}$ further readings were required. Recording started one to two weeks before the summer vacation and continued during the three weeks of vacation and the first two weeks after return to work. One woman was examined before and after she was transferred to an unexposed job. Readings taken within 24 hours of starting work were classified as "at work" and compared with readings taken on days with no work exposure at all, as proposed by Burge. ${ }^{6}$ The mean, maximum, and minimum PEF were plotted for each day and the diurnal variation for each day calculated as (highest-lowest) highest. Each record was assessed by one of the authors (SB) without knowledge of the workers' history, bronchial reactivity, responses on the diary card, spirometry results, or job exposures. Each work period was assessed to see whether deterioration occurred and each period away from work to see whether improvement occurred.

The records were plotted and we accepted a diurnal variation in PEF of more than $15 \%$ as indicative of asthma. ${ }^{7}$ The criteria for definite occupational asthma were subjective, as proposed by Burge. ${ }^{6}$ They included characteristic peak flow patterns with deterioration of PEF in work periods and improvement on holiday or rest days. ${ }^{6}$ Mean peak flow on work days was compared with that on unexposed days.

\section{RECORDING OF SYMPTOMS}

Dyspnoea, wheeze, and cough were recorded every day, 6-8 hours after the shift or in the evenings during unexposed periods, and graded from 0 to 3 . The daily symptom score was computed by simple addition of each score.

\section{BRONCHIAL RESPONSIVENESS}

Subjects were asked not to smoke in the two hours before their appointment and to use an inhaled bronchodilator within six hours. Responsiveness to metacholine was measured before and after the holiday period, as des-

Table 2 Details of potroom workers studied

\begin{tabular}{|c|c|c|c|c|c|c|c|}
\hline $\begin{array}{l}\text { Subject } \\
\text { No }\end{array}$ & $\begin{array}{l}\text { Age } \\
\text { (years) }\end{array}$ & Sex & Smoking & Atopy & $\begin{array}{l}\text { Length of } \\
\text { employment } \\
\text { (years) }\end{array}$ & $\begin{array}{l}\text { Length of } \\
\text { exposure } \\
\text { before } \\
\text { symptoms } \\
\text { started } \\
\text { (years) }\end{array}$ & $\begin{array}{l}F E V, \% \\
\text { predicted }\end{array}$ \\
\hline 1 & 42 & $\mathbf{M}$ & Non-smoker & 0 & 23 & 22 & 82 \\
\hline 2 & 46 & M & Ex-smoker & 0 & 21 & 3 & 91 \\
\hline 3 & 50 & $\mathbf{M}$ & Non-smoker & 0 & 28 & 6 & 108 \\
\hline 4 & 26 & $\mathbf{M}$ & Smoker & + & 8 & 2 & 103 \\
\hline 5 & 26 & M & Smoker & 0 & 5 & 0.5 & 108 \\
\hline 6 & 32 & $\mathbf{M}$ & Smoker & + & $2 \cdot 5$ & 1.5 & 101 \\
\hline 7 & 30 & $\mathbf{M}$ & Smoker & 0 & 12 & 12 & 94 \\
\hline 8 & 48 & $M$ & Non-smoker & 0 & 27 & 26 & 81 \\
\hline 9 & 25 & $\mathbf{M}$ & Non-smoker & + & 4 & 3 & 107 \\
\hline 10 & 47 & $\mathbf{M}$ & Smoker & 0 & 26 & 17 & 92 \\
\hline 11 & 42 & $\mathbf{F}$ & Smoker & 0 & 9 & 7 & 99 \\
\hline 12 & 28 & $\mathbf{M}$ & Smoker & & 5 & 4 & 79 \\
\hline 13 & 44 & $\mathbf{M}$ & Non-smoker & + & 28 & 17 & 93 \\
\hline 14 & 48 & $\mathbf{M}$ & Ex-smoker & 0 & 22 & 20 & 91 \\
\hline
\end{tabular}


Table 3 Analyses of peak flow measurements during workdays, holiday, and rest days

\begin{tabular}{|c|c|c|c|c|c|c|c|}
\hline \multirow{2}{*}{$\begin{array}{l}\text { Subject } \\
\text { No }\end{array}$} & \multirow{2}{*}{$\begin{array}{l}\text { Duration } \\
\text { of study } \\
\text { (days) }\end{array}$} & \multirow{2}{*}{$\begin{array}{l}\text { Holiday } \\
\text { (days) }\end{array}$} & \multirow{2}{*}{$\begin{array}{l}\text { Deterioration } \\
\text { during } \\
\text { work weeks† }\end{array}$} & \multicolumn{2}{|c|}{ Improvement } & \multirow{2}{*}{$\begin{array}{l}\text { Maximum } \\
\text { diurnal } \\
\text { variation (\%) }\end{array}$} & \multirow{2}{*}{$\begin{array}{l}\text { Correlation } \\
\text { of daily, } \\
\text { minimum } \\
\text { PEF and } \\
\text { symptoms (r) }\end{array}$} \\
\hline & & & & Rest day $\ddagger$ & Holiday & & \\
\hline \multicolumn{8}{|c|}{ Definite occupational asthma } \\
\hline 1 & 56 & 23 & $3 / 4$ & $2 / 4$ & + & 28 & $-0 \cdot 78^{\star \star}$ \\
\hline 2 & 48 & 20 & $2 / 3$ & $0 / 3$ & + & 16 & $-0 \cdot 75^{\star \star}$ \\
\hline 3 & 40 & 16 & $4 / 4$ & $3 / 4$ & + & 30 & Nil \\
\hline 4 & 62 & 22 & $4 / 5$ & $4 / 4$ & 0 & 20 & $-0.56^{\star \star}$ \\
\hline 5 & 47 & 21 & $3 / 4$ & $2 / 3$ & + & 41 & $-0 \cdot 87^{\star \star}$ \\
\hline 6 & 47 & 24 & $3 / 3$ & $0 / 1$ & + & 53 & $-0 \cdot 30 \mathrm{NS}$ \\
\hline 7 & 48 & 21 & $2 / 3$ & $1 / 2$ & + & 29 & $-0 \cdot 55^{\star \star}$ \\
\hline 8 & 47 & 21,12 & $3 / 3$ & $2 / 2$ & + & 17 & NA \\
\hline 9 & 35 & 24 & $1 / 2$ & $0 / 2$ & + & 18 & $-0.54^{\star}$ \\
\hline 10 & 49 & 23 & $2 / 2$ & $0 / 1$ & + & 16 & $-0.38^{\star}$ \\
\hline \multicolumn{8}{|c|}{ Probable occupational asthma } \\
\hline 11 & 34 & 0 & $2 / 3$ & $1 / 3$ & & 25 & $-0.51 \star \star$ \\
\hline \multicolumn{8}{|c|}{ Irritant reaction } \\
\hline 12 & 68 & 55 & $1 / 1$ & $1 / 1$ & + & 15 & $-0.47^{\star \star}$ \\
\hline 13 & 49 & 23 & $3 / 4$ & $2 / 3$ & 0 & 4 & No symptoms \\
\hline \multicolumn{8}{|c|}{ Inadequate record } \\
\hline 14 & 35 & 24 & NA & NA & NA & NA & NA \\
\hline
\end{tabular}

${ }^{\star} \mathrm{p}<0.05 ;{ }^{\star \star} \mathrm{p}<0.001$.

tThe denominator gives the number of work weeks evaluated and the numerator is the number of work weeks with deterioration in peak flow.

$\ddagger$ The denominator gives the number of rest days evaluated and the numerator is the number of rest days with improvement in peak flow.

NA-Not assessable.

cribed by Cockroft, ${ }^{8}$ with the modification that the initial concentration of methacholine was $0 \cdot 125 \mathrm{~g} / 1^{9}{ }^{9}$ The tests were omitted if respiratory infection was reported within the past six weeks. The nebuliser was calibrated to give a constant output of $0.130 \mathrm{ml} / \mathrm{minute}$. Doubling concentrations of methacholine were inhaled at 5 minute intervals until a concentration of 32 $\mathrm{g} / \mathrm{l}$ was reached or the $\mathrm{FEV}_{1}$ had fallen by more than $20 \%$ from the baseline value. $\mathrm{FEV}_{1}$ was measured 30 and 90 seconds after each dose with a dry bellow spirometer (Jones Pulmonaire). $\mathrm{PC}_{20}$ was estimated by linear interpolation on a logarithmic scale by using the data of the last two points on the non-cumulative doseresponse curve. If the fall in $\mathrm{FEV}_{1}$ from baseline value was less than $20 \%, \mathrm{PC}_{20}$ was extrapolated by a linear model from all the data points. Normal bronchial reactivity was defined as $\mathrm{PC}_{20}$ greater than $8 \mathrm{~g} / \mathrm{l}^{8}$

\section{BLOOD MEASUREMENTS}

Venous blood was taken into EDTA just before the methacholine challenge test. Eosinophil counts were performed with a Fuchs-Rosenthal counting chamber and expressed as total number of eosinophils per litre. Counts were performed by one observer who had no knowledge of the subject's exposure or $\mathrm{PC}_{20}$ methacholine. Total IgE was measured by a commercial laboratory (Nycomed, Oslo).

ANALYSIS

Comparison of daily mean PEF between exposed and unexposed periods was done by the two sample $t$ test (pooled variance estimate). The analysis was performed with the statistical package for the social sciences (SPSS-PC). ${ }^{10}$ Symptom scores for rest days were compared with the symptom scores for the working periods by the two sample $t$ test (separate variance estimate). ${ }^{10}$ Daily symptom scores were plotted against minimum values of PEF; as this fitted a straight line in most cases, their relation was assessed with the Pearson correlation coefficient. ${ }^{11}$

\section{Results}

Thirteen workers kept good quality peak flow records. One record was inadequate as recordings were only to the nearest $50 \mathrm{l} /$ minute (subject 14); one subject did not record symptoms (subject 8) (tables 3 and 4). Assessment of the records showed a high probability of work related effects in 10 of the 13 subjects $(1-10)$ with adequate records and probable work related asthma in one of the three remaining workers (subject 11), who kept only a short record after moving away from the potroom and who had no holiday record (table 3 ). The size of diurnal changes in peak flow observed varied considerably among workers. Ten records showed a diurnal variation of more than $15 \%$ in peak flow in exposed periods and fulfilled our criteria for definite occupational asthma (figs 1 and 2). Two records (subjects 12 and 13) showed smaller changes (fig 3 ).

There was a good correlation between minimum peak flow and daily symptoms in nine of the 10 workers who had symptoms and adequate peak flow records (table 3). Mean PEF was significantly higher in unexposed periods in all 10 subjects considered to have definite occupational asthma (table 4). Five of these showed at least a doubling of $\mathrm{PC}_{20}$ methacholine before returning to work after the holiday. However, methacholine reactivity was within the normal range in nine of 13 subjects on work days (table 4). Ten of the 12 workers who kept adequate records during the three 
Table 4 Lung function, symptoms eosinophil count, and IgE concentration during working periods and on holiday

\begin{tabular}{|c|c|c|c|c|c|c|c|c|c|c|c|c|}
\hline \multirow[b]{2}{*}{$\begin{array}{l}\text { Subject } \\
\text { No }\end{array}$} & \multicolumn{2}{|c|}{$F E V_{1}(L)$} & \multicolumn{2}{|c|}{$P C_{20}(g / l)$} & \multicolumn{2}{|c|}{ Mean PEF (l/min) } & \multicolumn{2}{|c|}{$\begin{array}{l}\text { Sum of } \\
\text { symptoms } \dagger\end{array}$} & \multicolumn{2}{|l|}{$\operatorname{Ig} E$} & \multicolumn{2}{|c|}{$\begin{array}{l}\text { Eosinophils } \\
\text { (count 46) }\end{array}$} \\
\hline & $\begin{array}{l}\text { Before } \\
\text { holiday }\end{array}$ & $\begin{array}{l}\text { After } \\
\text { holiday }\end{array}$ & $\begin{array}{l}\text { Before } \\
\text { holiday }\end{array}$ & $\begin{array}{l}\text { After } \\
\text { holiday }\end{array}$ & $\begin{array}{l}\text { At } \\
\text { work }\end{array}$ & $\begin{array}{l}\text { On } \\
\text { holiday }\end{array}$ & $\begin{array}{l}\text { At } \\
\text { work }\end{array}$ & $\begin{array}{l}\text { On } \\
\text { holiday }\end{array}$ & $\begin{array}{l}\text { Before } \\
\text { holiday }\end{array}$ & $\begin{array}{l}\text { After } \\
\text { holiday }\end{array}$ & $\begin{array}{l}\text { Before } \\
\text { holiday }\end{array}$ & $\begin{array}{l}\text { After } \\
\text { holiday }\end{array}$ \\
\hline 1 & 3.58 & $3 \cdot 64$ & $3 \cdot 3$ & $2 \cdot 8$ & 495 & $515^{\star \star}$ & $2 \cdot 2$ & $0^{\star \star}$ & 26 & 26 & 313 & 63 \\
\hline 2 & 3.61 & $3 \cdot 54$ & $2 \cdot 7$ & $3 \cdot 1$ & 483 & $538^{\star}$ & $2 \cdot 7$ & $1 \cdot 3^{\star \star}$ & 37 & 45 & 219 & 294 \\
\hline 3 & $4 \cdot 75$ & $4 \cdot 42$ & $29 \cdot 5$ & $11 \cdot 4$ & 594 & $632^{\star \star}$ & 0 & 0 & 178 & 323 & 450 & 230 \\
\hline 4 & $5 \cdot 0$ & & $12 \cdot 6$ & & 506 & $518^{\star}$ & $3 \cdot 8$ & $0 \cdot 3^{\star \star}$ & & 175 & & \\
\hline 5 & 5.95 & 6.01 & $21 \cdot 8$ & $44 \cdot 7$ & 651 & $695^{\star \star}$ & $1 \cdot 4$ & $0^{\star \star}$ & 36 & 46 & 300 & 231 \\
\hline 6 & $4 \cdot 83$ & $5 \cdot 21$ & 3.5 & $9 \cdot 7$ & 471 & $496 \star$ & $1 \cdot 3$ & $0 \cdot 3 \star \star$ & 61 & 86 & 269 & 81 \\
\hline 7 & $4 \cdot 52$ & $4 \cdot 74$ & $19 \cdot 5$ & $48 \cdot 9$ & 486 & $504^{\star \star}$ & $3 \cdot 2$ & $1 \cdot 3^{\star \star}$ & 123 & 73 & 225 & 169 \\
\hline 8 & 3.65 & 3.79 & $11 \cdot 4$ & $77 \cdot 5$ & 399 & $458^{\star \star}$ & NA & NA & 58 & 76 & 113 & 119 \\
\hline 9 & $5 \cdot 3$ & $5 \cdot 61$ & $9 \cdot 7$ & $42 \cdot 4$ & 479 & $554^{\star \star}$ & $1 \cdot 7$ & $0.9 \mathrm{NS}$ & 78 & 82 & 250 & 250 \\
\hline 10 & 3.85 & $3 \cdot 61$ & $>32$ & $>32$ & 552 & $569 \star$ & $0 \cdot 6$ & 0 NS & 68 & 73 & 206 & 181 \\
\hline 11 & & & & & & & & & & & & \\
\hline 12 & $3 \cdot 6$ & & 4.5 & & 429 & $452^{\star \star}$ & $4 \cdot 7$ & $3 \cdot 1^{\star \star}$ & NA & NA & NA & NA \\
\hline 13 & 3.93 & 4.03 & $22 \cdot 3$ & $29 \cdot 6$ & 503 & 504 NS & 0 & 0 & 216 & 267 & 125 & 109 \\
\hline 14 & $3 \cdot 58$ & $3 \cdot 67$ & $20 \cdot 7$ & $55 \cdot 8$ & NA & NA & 0.5 & $0 \cdot 2^{\star}$ & 31 & 16 & 163 & 112 \\
\hline
\end{tabular}

${ }^{\star} \mathrm{p}<0.05,{ }^{\star \star} \mathrm{p}<0.001$.

†Arithmetic mean of daily sum of symptoms (dyspnoea, wheezing, and cough) in each period.

+ Subject 11 had no holiday record.

NA-Not assessable.

week holiday showed definite improvement in peak flow (table 3). Changes in $\mathrm{FEV}_{1}$ were trivial. Of ten symptomatic workers, eight showed a significant fall in the mean of daily symptom scores while on holiday (table 4). The blood eosinophil count fell while on holiday in eight of 11 workers who had counts before and after the holiday (table 4). Small increases in total IgE occurred in eight of the 13 workers (table 4).

\section{Discussion}

Fourteen of 379 workers had symptoms suggestive of occupational asthma, according to the plant physician, and a measurable $\mathrm{PC}_{20}$ methacholine; this compares with the average prevalence of $4-10 \%$ from published studies in

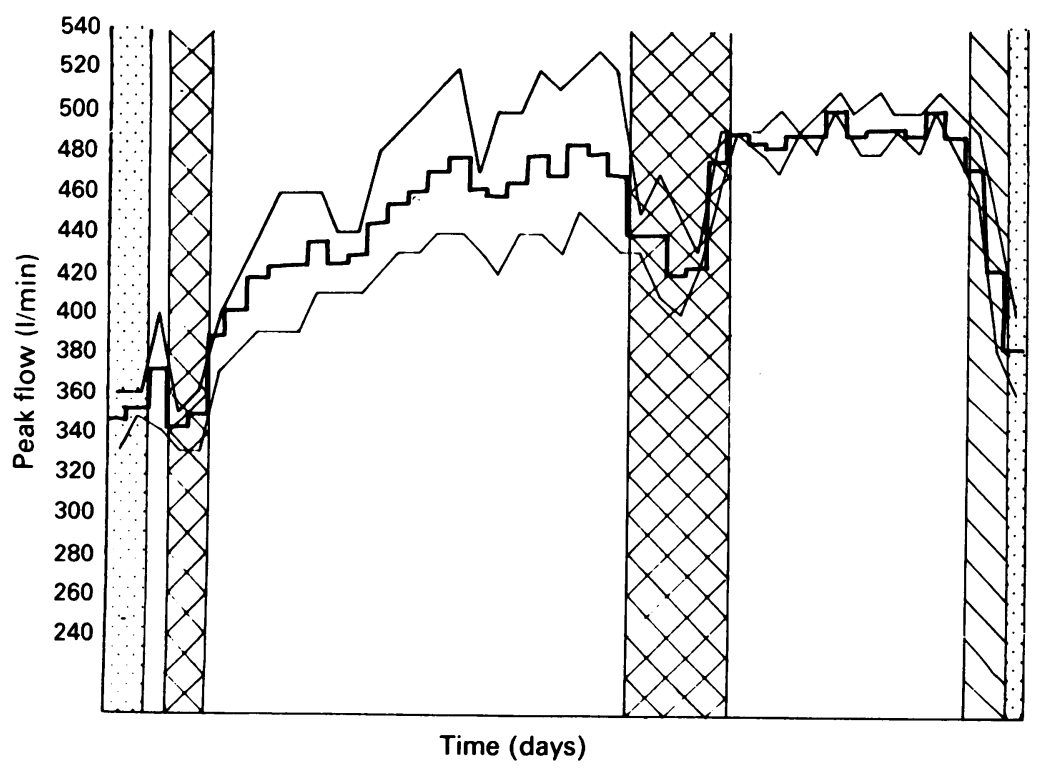

Figure 1 Plot of daily maximum (top line), mean (middle line), and minimum (bottom line) peak flow in prebake pot operator (subject 8). Days at work have shaded background (dots, day shift; crosshatch, night shift; backslash, afternoon shift), days away from work have clear background. Deterioration occurred in all three work periods (with recovery on last nightshift worked), with improvement in both periods off work and during holiday. Diurnal variation in peak flow increased as recovery occurred (without specific treatment) and reached 17\%. Conclusion: definite work related asthma. symptomatic smelters. ${ }^{1213}$ The criteria for occupational asthma were met by 10 workers, with increased diurnal variation in peak flow, consistent deterioration at work and improvement away from work, and similar changes in respiratory symptoms. Subjective assessment of PEF records has been shown to be better than statistical evaluation of PEF data in detecting occupational asthma. ${ }^{14}$ Nevertheless, mean PEF on work days in the 10 asthmatic subjects was lower than on unexposed days, supporting the subjective assessment of PEF records. We may have underestimated the pevalence of occupational asthma as it is possible that workers could have potroom asthma despite an $\mathrm{FEV}_{1}$ below $80 \%$ predicted or $\mathrm{aPC}_{20}$ to methacholine above $32 \mathrm{~g} / \mathrm{l}$.

Peak flow measurements did not show a consistent pattern of deterioration on each work day but deterioration did occur on some work days, suggesting that exposure was significantly higher on some days. However, most of the records showed progressive daily deterioration, with recovery taking several days after exposure stopped (fig 1). This pattern is usually seen in situations where sensitisation is thought to occur, as with exposure to colophony and isocyanate. ${ }^{34}$ No records showed a maximal reaction on the first workday, as occurs in metal fume fever, cotton workers, and some workers exposed to microbiological aerosols. ${ }^{15}$

Two workers showed a diurnal variation in peak flow within the normal range ( $\leqslant 15 \%)$ and only a small fall on work days, which might be interpreted as an irritant effect or the result of very low exposure in a sensitised worker. This pattern has been reported in workers with severe occupational asthma after prolonged exposure, ${ }^{6}$ but the lack of improvement in PEF during a three week holiday does not favour this hypothesis. The existence of a small irritant effect superimposed on pre-existing airways obstruction is less likely because of the lack of appreciable methacholine reactivity. These small changes may have been due to very low exposure as one subject worked in an 


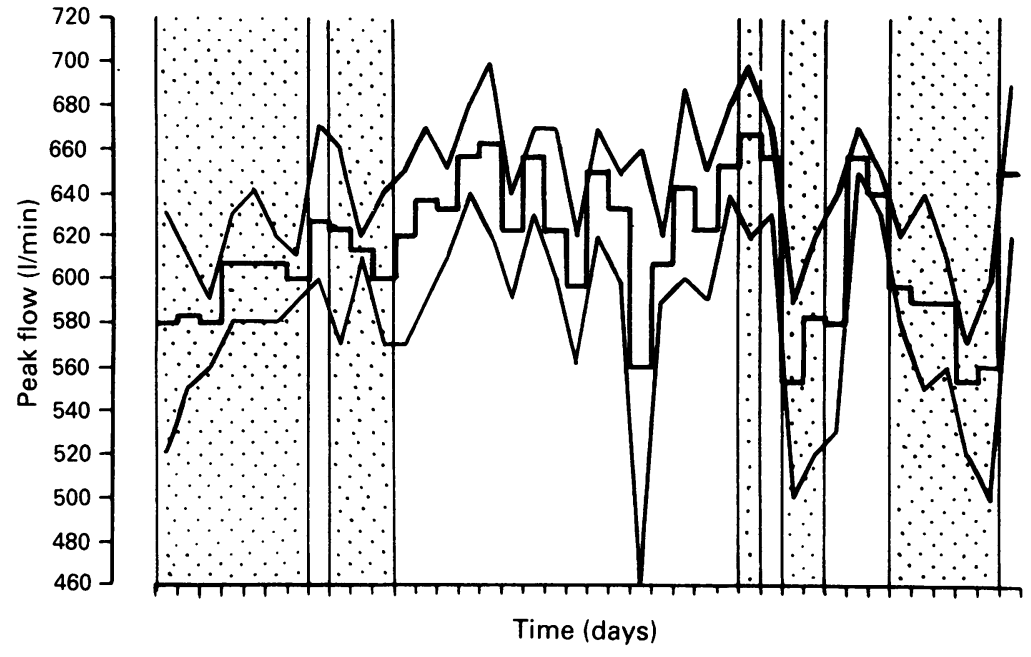

Figure 2 Plot of daily maximum (top line), mean (middle line), and minimum (bottom line) peak flow in Soderberg pot service worker (subject 3). Days at work have shaded background (dots, day shift), days away from work clear background. Deterioration occurred in all of four evaluable work periods and improvement in three of four weekends and during holiday. First work week is difficult to evaluate as increasing minimum values are sometimes due to learning effect; this week has therefore been omitted from the evaluation. One bad day observed during holiday period (day of 50th birthday party). Diurnal variation in peak flow reached $30 \%$. Conclusion: definite work related asthma. airconditioned cab and respiratory protection was available for all workers and generally worn during times of higher exposure.

The later time of waking on days not at work combined with the small number of daily readings could have introduced some bias. This should have improved the minimum value each day, which in general was not seen. The most consistent findings at work were slight reductions in the maximum daily peak flow, which usually occurred in the middle of the day.

Peak flow was measured only three times each day. This is less than optimal and may have resulted in no readings being made in the workplace. Infrequent readings tend to underestimate diurnal variation in peak flow and produce more variable records. ${ }^{16}$ Thrice daily readings failed to show work related effects in a group of hairdressers sensitised to

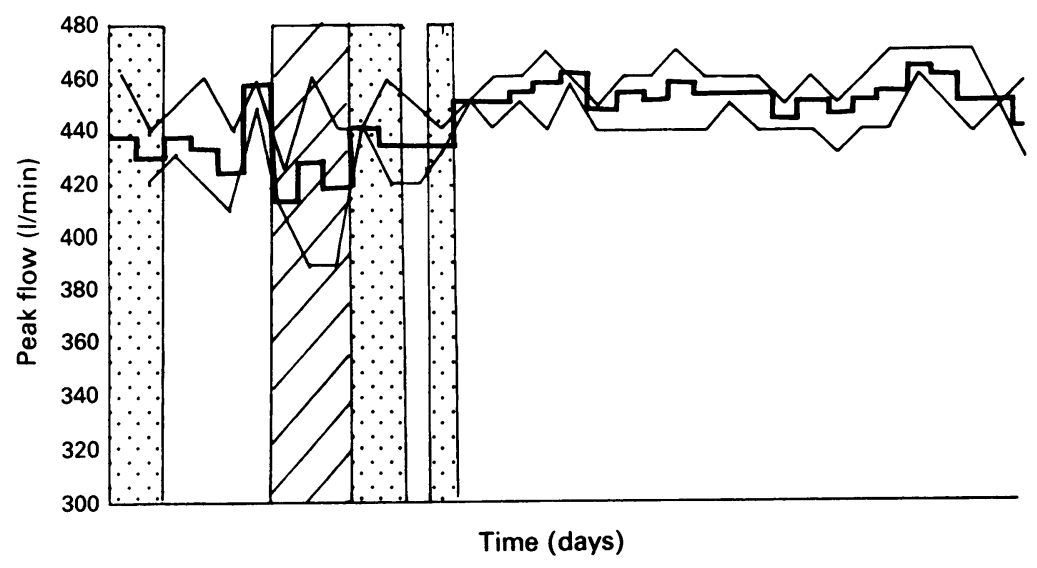

Figure 3 Plot of daily maximum (top line), mean (middle line), and minimum (bottom line) peak flow in crane operator (subject 12). Days at work have shaded background (dots, day shift), days away from work have clear background.

Deterioration occurred in the one evaluable work week and improvement in one weekend and on holiday. Diurnal variation in peak flow remained below $15 \%$ and deterioration at work was slight. Conclusion: small consistent work related effects of uncertain mechanism. persulphates. ${ }^{16}$ The work related changes seen in our study are therefore all the more impressive.

Potroom fumes contain sulphur dioxide and hydrogen fluoride, known respiratory irritants that many believe are the cause of disease in exposed workers. ${ }^{217}$ There is some evidence that the effects of irritants alone may be sufficient to induce work related asthma. ${ }^{18} \mathrm{It}$ is also likely that the irritants present are working synergistically with sensitisers, as yet not clearly defined. Evidence is growing that the irritant effects of cigarette smoke increase absorption of workroom dusts (for example in electroplate workers), increase IgE sensitisation (for example in acid anhydride workers), ${ }^{19}$ and increase occupational asthma (for example in platinum refiners ${ }^{20}$ and electronics workers exposed to colophony). ${ }^{21}$ The combination of an irritant and a sensitiser is therefore optimal for causing occupational asthma.

Responsiveness to methacholine was within the normal range in seven of the 10 subjects diagnosed as having occupational asthma Some investigators require hyperresponsiveness before asthma can be diagnosed. However hyperresponsiveness is usually not a feature of immediate asthmatic reactions and is variable in late asthmatic reactions, being related mostly to increased dose of allergen. ${ }^{22}$ The lack of severe reactions in our study is likely to explain the lack of hyperresponsiveness in some workers. Nevertheless, at least a doubling in responsiveness occurred in six of 11 workers with paired readings before and after a three week holiday, though one worker was less responsive after the holiday. Methacholine reactivity was measured in the original cross sectional study of this workforce..$^{9}$ A correlation was found between symptoms and hyperresponsiveness, but many symptomatic workers had no demonstrable hyperresponsiveness. If the respiratory disease is due to an irritant effect alone there should be a good correlation between potroom asthma and results of tests of non-specific responsiveness.

There are no definite respiratory sensitisers as major constituents of the fumes. Chemical workers exposed to aluminium fluoride have been shown to develop airways obstruction, which improves away from exposure. However, specific provocation tests with aluminium fluoride have not caused immediate or delayed ashmatic reactions after short exposures, although non-specific hyperresponsiveness may have altered in a manner suggesting hypersensitivity. ${ }^{23}$ Some minor constituents of the dust are known sensitisers-for example, chromium, nickel, and perhaps vanadium. Whether exposure to these sentitisers in the potroom is sufficient to cause disease is not known.

1 Frostad AW. Fluorine intoxication in Norwegian aluminium plant workers. Tidsskr Nor Laegefor 1936;56:179-82. (In Norwegian.)

2 Abramson MJ, Wlodarczyk JH, Saunders NA, Hensley MJ. Does aluminum smelting cause lung disease? Am Rev Resp Dis 1989;139:1042-57.

3 Burge PS, O'Brien IM, Harries MG. Peak flow rate records in the diagnosis of occupational asthma due to colophony. Thorax 1979;34:308-16. 
4 Burge PS, O'Brien IM, Harries MG. Peak flow rate records in the diagnosis of occupational asthma due to isocyanates. Thorax 1979;34:317-23.

5 Cartier A, Pineau L, Malo J-L. Monitoring of maximum expiratory peak flow rates and histamine inhalation tests in the investigation of occupational asthma. Clin Allergy 1984;14:193-6.

6 Burge PS. Single and serial measurements of lung function in the diagnosis of occupational asthma. Eur J Resp Dis 1982;63 (suppl 123):47-59.

7 Ghio AJ, Castellan RM, Kinsley KB, Hankinson JL. Changes in forced expiratory volume in one second and peak expiratory flow rate across a work shift among unexposed blue collar workers. Am Rev Respir Dis 1991;143:1231-4.

8 Cockcroft DW, Killian DN, Mellon JJA, Hargreave FE Bronchial reactivity to inhaled histamine: a method and clinical survey. Clin Allergy 1977;7:235-43.

9 Kongerud J, Søyseth V. Methacholine responsiveness, respiratory symptoms and pulmonary function in aluminium potroom workers. Eur Respir J 1991;4:159-66.

10 Norusis MJ. SPSS/PC+,V 3.0 Statistical package for the social sciences. Chicago: SPSS 1989.

11 Armitage P, Berry G. Statistical methods in medical research. 2nd ed. Oxford: Blackwell Scientific, 1987.

12 Bruusgaard A. Asthma-like disease among Norwegian aluminium plant workers. Tidsskr Nor Laegerfor 1960;80:796-7. (In Norwegian.)

13 Saric M, Zushkin E, Gomzi M. Bronchoconstriction in potroom workers. Br J Ind Med 1979;36:211-5.

14 Burge PS. Prolonged and frequent recordings of peak expiratory flow rate in workers with suspected occupational asthma due to colophony and isocyanates.
(Msc thesis), London: London School of Hygiene and Tropical Medicine, University of London, 1978.

15 Burge PS, Finnegan M, Horsfield N, Emery D, Austwick P, Davies PS, et al. Occupational asthma in a factory with a contaminated humidifier. Thorax 1985;40:248-54.

16 Blainey AD, Ollier S, Cundell D, Smith RE, Davies RJ. Occupational asthma in a hairdressing salon. Thorax 1986;41:42-50.

17 Saric M, Gomzi M, Godnic-Cvar J, Stilinovic L. The role of atopy in potroom workers' asthma. Am J Ind Med 1986;9:239-42.

18 Tarlo SM, Broder I. Irritant-induced occupational asthma. Chest 1989;96:297-300.

19 Venables KM, Topping MD, Howe W, Luczynska CM Hawkins R, Newman Taylor AJ. Interaction of smoking and atopy in producing specific $\operatorname{IgE}$ antibody against a hapten protein conjugate. $B M J 1985 ; 290: 201-4$.

20 Venables KM, Dally MB, Nunn AJ, Stevens JF, Stephens $\mathrm{R}$, Farrer N, et al. Smoking and occupational allergy in workers in a platinum refinery. BMJ 1989;299:939-42.

21 Burge PS, Perks W, O'Brien IM, Hawkins R, Green M Occupational asthma in an electronics factory. Thorax 1979;34:13-8.

22 Durham SR, Graneek BJ, Hawkins R, Newman Taylor AJ. The temporal relationship between increases in airway responsiveness to histamine and late asthmatic responses induced by occupational agents. J Allergy Clin Immunol 1987;79:398-406.

23 Simonsson BG, Sjøberg A, Rolf C, Haeger-Aronsen B. Acute and long-term airway hyperreactivity in aluminium-salt exposed workers with nocturnal asthma. Eur $J$ Respir Dis 1985;66:105-18.

\section{Comroe in Philadelphia}

Before becoming director of the Cardiovascular Research Institute in San Francisco in the 1950s Julius Comroe was professor of physiology and pharmacology in the University of Pennysylvania. Although Comroe was not himself a clinician, he succeeded in attracting young chest physicians to Philadelphia from all corners of the world and physiological techniques developed in his department, such as body plethysmography and single breath measurements of ventilation and diffusion, have come into widespread clinical use.

In those days, Comroe was in his mid 40s, a small man with a slow drawling voice, a mischievous glint in his eye, and a wry sense of humour. I believe that the secret of his success with scientifically illiterate clinicians like myself was his unique ability to translate complex physiological concepts into simple terms. His classical monograph The Lung was a model of clarity, and in his famous "Retrospectroscope" series in the American Review of Respiratory Diseases he emphasised the fundamental simplicity of many of the great advances in respiratory medicine. He rejected technical jargon and, in this respect, was especially critical of his fellow physiologists. He told me how, in the last war, the American forces used Navajo Indians as signallers because their obscure language was incomprehensible to the enemy. In the next war, said Comroe, they'll use respiratory physiologists. When one of his senior staff had given a 40 minute seminar on ventilationperfusion relationships, covering the blackboard with a multitude of symbols and equations, Comroe rose from his seat, slowly cleared the blackboard, then handed back the chalk to the speaker with the words: "Now, let's have it in English." Comroe was intolerant of shoddy and careless presentations. When he was chairing a symposium one of the contributors, who had gone well over his time by showing an excessive number of indecipherable slides, was delaying matters still further by making the projectionist seek out a missing slide. Comroe stepped forward, drew a small package from his pocket, and held it out to the speaker saying: "I've got a slide. Will this do?"

The humour, the simplicity, and the wisdom of Comroe is well summarised in his now famous definition of a "normal subject." A normal subject, said Comroe, is one who has not been properly investigated.

COLIN M OGILVIE 